\title{
In-depth Analysis of Tax Policy for Encouraging Enterprises to Increase Investment in R\&D*
}

\author{
Zilan Wang \\ Dianchi College of Yunnan University \\ Kunming, China 650228
}

\begin{abstract}
Science and technology is the weapon of a country and the important force for the development of a country and a nation. Innovation is the first driving force for development and the strategic support for building a modern economic system. In recent years, the Ministry of Finance, the State Administration of Taxation and other relevant departments have successively issued a number of taxation policies, encouraging enterprises to increase investment in research and development of new technologies, new products and new processes. This paper sorts out the relevant documents on pre-tax deduction of research and development expenses in recent years, analyzes the changes of policies, and puts forward reasonable suggestions for enterprises to effectively use these preferential policies.
\end{abstract}

Keywords-R\&D expenses; tax incentives; additional deduction

\section{INTRODUCTION}

In recent years, China's economy has gradually shifted from a high-speed growth stage to a high-quality development stage. Changing the development mode, transforming the growth momentum, and optimizing the economic structure have become the top priorities of China's economic development. The report of the 19th National Congress of the Communist Party of China clearly stated that we should deepen the reform of the science and technology system, establish a technological innovation system with enterprises as the mainstay, market-oriented, and deep integration of production, education and research, strengthen support for middle and small-sized enterprises' innovation, and promote the transformation of scientific and technological achievements. In order to promote enterprises to increase investment in research and development, the Ministry of Finance and the State Administration of Taxation have successively issued policy documents for pre-tax deduction of the research and development expenses of various enterprises.

\section{SORTING OUT THE TAX POLICY FOR ENCOURAGING ENTERPRISES TO INCREASE INVESTMENT IN R\&D}

In 2007, the first Item of Article 30 of the Enterprise Income Tax Law passed at the Fifth Session of the Tenth

*Fund Project: Science Research Fund Project for Yunnan Provincial Department of Education: Research on the Course Construction of Tax Accounting and Tax Planning Based on the Cultivation of Innovative and Entrepreneurial Talents

Project Code: 2018JS742.
National People's Congress stipulates, "The research and development expenses incurred by enterprises in the development of new technologies, new products and new processes can be deducted when calculating the taxable income". Subsequently, the State Council promulgated the Regulations on the Implementation of the Enterprise Income Tax Law. Article 95 of the Regulations stipulates, "For the research and development expenses incurred by enterprises for the development of new technologies, new products, and new processes, if the intangible assets have not been formed, they are included in the current profits and losses, on the basis of deduction according to the provisions, they are deducted $50 \%$ of the research and development expenses; if the intangible assets are formed, they are amortized according to $150 \%$ of the cost of intangible assets".

In November 2015, in order to standardize the implementation of the pre-tax additional deduction policy for the research and development expenses, the Ministry of Finance, the State Administration of Taxation and the Ministry of Science and Technology jointly issued the Notice on Improving the Pre-tax Additional Deduction Policy for the Research and Development Expenses (CS [2015] No. 119). The document clarifies the scope of the R\&D activities and R\&D expenses, and clearly defines the scope of the R\&D expenses that allow for additional deductions and the nonapplicable pre-tax additional deduction policy. At the same time, it has clearly stipulated the pre-tax additional deduction policy for the R\&D expenses incurred by enterprises engaged in special matters such as research and development, joint development projects, centralized R\&D projects for enterprise groups, and creative design by external associated organizations or individuals. Subsequently, in order to implement the CS [2015] No. 119 document, the State Administration of Taxation issued the Announcement on Issues Concerning the Pre-tax Additional Deduction Policy for Enterprise Research and Development Expenses in December 2015 (No. 97 Announcement by State Administration of Taxation Announcement in 2015, hereinafter referred to as No. 97 Announcement), the document has made more detailed provisions on the scope of the research and development personnel, the collection of expenses, and the entrustment of research and development.

In order to further improve the implementation of the pretax additional deduction and preferential policies for the research and development expenses, and effectively solve the problems in the implementation of the policy, according to the 
provisions of CS [2015] No. 119 and No. 97 Announcement by State Administration of Taxation Announcement in 2015 (hereinafter referred to as "No. 97 Announcement") and other documents, the State Administration of Taxation issued the Announcement on Issues Concerning the Collection Scope of Pre-tax Addition Deduction of the Research and Development Expenses on November 8, 2017 (No. 40 by State Administration of Taxation Announcement in 2017, hereinafter referred to as "No. 40 Announcement"). On September 20, 2018, the Ministry of Finance, the State Administration of Taxation, and the Ministry of Science and Technology jointly issued the Notice on Increasing the Pre-tax Deduction Ratio of the Research and Development Expenses(CS [2018] No. 99, hereinafter referred to as "No. 99 Document ").

\section{ENCOURAGING ENTERPRISES TO INCREASE MAJOR} ADJUSTMENTS IN TAXATION POLICIES FOR R\&D INVESTMENT

No. 99 Document further encourages enterprises to increase investment in research and development, support technological innovation, and once again increase the pre-tax additional deduction ratio of the research and development expenses of enterprises. No. 40Announcement revolves around the collection scope of the research and development expenses. Based on the current regulations, combined with the actual situation, it has improved and clarified the scope and caliber of some research and development expenses, ensuring the systemic and completeness of the policy.

\section{A. Increasing the Pre-tax Additional Deduction Ratio}

It's based on the provisions of No. 99Document: During the process of $R \& D$ activities, if the intangible assets have not been formed, the actual R\&D expenses incurred by the enterprise shall be included in the current profit and loss. When deducted according to the provisions, they shall be deducted before tax according to $75 \%$ of the actual amount during the period from January 1, 2018 to December 31, 2020; if the intangible assets are formed, they are amortized before tax in accordance with $175 \%$ of the cost of intangible assets during the above period. According to this provision, the deduction ratio of the research and development expenses increases from $50 \%$ to $75 \%$, and the pre-tax deduction is increased, further reducing the tax burden of enterprises.

\section{B. Expanding the Scope of Additional Deductions}

No. 40 Announcement retains No. 97 Announcement on the definition of the scope of personnel engaged in the research and development activities and the collection requirement of accurate labor costs for personnel engaged in various activities, and increases related matters such as labor dispatching and equity incentives.

1) Broadening the scope of external $R \& D$ personnel: The first article of CS [2015] No. 119 stipulates that: the research and development expenses include personnel labor costs, and personnel labor costs refer to wages and salaries, basic oldage insurance premiums, basic medical insurance premiums, unemployment insurance premiums, and work-related injury insurance premiums, maternity insurance premiums and housing provident fund for personnel directly engaged in research and development activities, as well as labor costs for external research and development personnel. No. 97 Announcement further explains this: The external research and development personnel of the enterprise refer to these who sign labor service agreement (contract) with the enterprise and the temporary employment of researchers, technicians and support personnel. According to the provisions of the above two documents, the wages and salaries paid directly to the research and development personnel are in the range of personnel labor costs, which can be deducted. The wages and salaries paid directly to the labor dispatching company and then paid to the research and development personnel by the labor dispatching company are not clearly defined in the provisions to enjoy the policy of additional deductions.

For the employment method of labor dispatching, whether the wages and salaries are paid directly to the employees or paid to the labor dispatching company, it is only a different payment method and does not change the essence of the labor dispatching work. In order to reflect the fairness of taxation, No.40 Announcement is based on the retention of CS [2015] No. 119 and No. 97 Announcement on the definition of the scope of personnel directly engaged in the R\&D activities and the labor costs accuracy of personnel engaged in various activities for collection requirement, and new adjustments are made to the R\&D personnel expenses for the employment method of labor dispatching in enterprise R\&D activities. Article 1 of No. 40 Announcement stipulates that: the external research and development personnel of the enterprise refer to these who sign labor service agreement (contract) with the enterprise and the temporary employment of researchers, technicians and support personnel. The enterprises accepting labor dispatching shall pay the labor dispatching enterprises in accordance with the agreement (contract), and the wages and salaries paid by the labor dispatching enterprises to the external R\&D personnel shall be the labor costs of the external R\&D personnel.

2) The equity incentives of $R \& D$ personnel included in the scope of additional deductions: Equity incentive is a special form of remuneration. It provides employees with certain ownership rights through conditional conditions, so that they have a sense of ownership, thus forming a community of interests with the enterprise and promoting the mutual growth of the enterprise and employees. It is a long-term incentive mechanism for enterprises to encourage and retain core research and development talents. CS [2015] No. 119 and No. 97 Announcement does not stipulate the equity incentive expenses paid to the research and development personnel. Item 2 of Article 1 in No. 40 Announcement clearly stipulates that: personnel labor costs, wages and salaries include expenditures on the research and development personnel equity incentives that can be deducted before tax.

3) Expanding the deduction range of other expenses: Article 6 of No. 40 Announcement makes adjustments to the scope of other related expenses. On the basis of the fees listed 
in CS [2015] No. 119, it is clarified that other related expenses include employee welfare expenses, supplementary old-age insurance premiums, and supplementary medical insurance premiums to further stimulate the enthusiasm of the R\&D personnel and promote the R\&D activities.

\section{Improving Policy Operability}

1) Improving the depreciation additional deduction policy for fixed assets that enjoy accelerated depreciation policy: Item 1 of Article 2 in No. 97 Announcement stipulates: If the instruments and equipments used by enterprises for research and development activities comply with the provision of tax laws and are chosen for the accelerated depreciation preferential policy, the additional deduction shall be carried out for the part of the depreciation and expenses that have been calculated by the accounting process when enjoying the additional deduction policy of the research and development expenses before tax. But they must not exceed the amount calculated according to the provision of tax law. This policy is actually lower of cost or market for accounting, tax law depreciation. The lower is deducted from the accounting processing calculation and the tax law depreciation. This calculation method can not only reflect the preference of the additional deduction policy, but also the operation is complicated and difficult to accurately grasp. Therefore, Item 2 of Article 3 in No. 40 Announcement makes adjustments to the depreciation additional deduction policy for fixed assets that enjoy the accelerated depreciation policy. Item 2 of Article 3 in Announcement stipulates: If the instruments and equipment used by enterprises for research and development activities comply with the provision of tax laws and are chosen for the accelerated depreciation preferential policy, the additional deduction is calculated for depreciation part of pretax deduction when enjoying the additional deduction policy of the research and development expenses before tax. For example:

In December 2017, a company purchased a set of special equipment for research and development. The original value of the equipment was 3 million Yuan. The estimated service life was 5 years, and the net residual value was not considered. According to the provision of tax law, the depreciation can be calculated by the sum-of-the-years-digits method, and the annual average method can be adopted for the accounting treatment. The calculation result is shown in "Table I".

TABle I. CAlculation Results of Deductible Amount of DePreciation Under Different Tax Policies

\begin{tabular}{|l|l|l|l|l|}
\hline Year & $\begin{array}{c}\text { Amount of depreciation } \\
\text { by accounting treatment }\end{array}$ & $\begin{array}{c}\text { Amount of depreciation } \\
\text { by the provision of tax } \\
\text { law }\end{array}$ & $\begin{array}{c}\text { Amount of depreciation } \\
\text { for Additional } \\
\text { deductions stipulated in } \\
\text { No. 97 Announcement }\end{array}$ & $\begin{array}{c}\text { Amount of } \\
\text { depreciation for } \\
\text { Additional deductions } \\
\text { stipulated in No. 40 } \\
\text { Announcement and No. } \\
\text { 99Document }\end{array}$ \\
\hline 2018 & RMB 600,000 Yuan & RMB 1,000,000 Yuan & RMB 300,000 Yuan & RMB 750,000 Yuan \\
\hline 2019 & RMB 600,000 Yuan & RMB 800,000 Yuan & RMB 300,000 Yuan & RMB 600,000 Yuan \\
\hline 2020 & RMB 600,000 Yuan & RMB 600,000 Yuan & RMB 300,000 Yuan & RMB 450,000 Yuan \\
\hline 2021 & RMB 600,000 Yuan & RMB 400,000 Yuan & RMB 200,000 Yuan & RMB 300,000 Yuan \\
\hline 2022 & RMB 600,000 Yuan & RMB 200,000 Yuan & RMB 100,000 Yuan & RMB 150,000 Yuan \\
\hline Total & RMB 3,000,000 Yuan & RMB 3,000,000 Yuan & RMB 1,200,000 Yuan & RMB 2,250,000 Yuan \\
\hline
\end{tabular}

As can be seen from the above example, the revision of this policy not only simplifies the operation, but also increases the amount of pre-tax deductions and reduces the tax burden.

2) Improving the intangible assets amortization additional deduction policy for enjoying the policy of shortening the amortization period: No. 97 Announcement stipulates for the collection of intangible assets amortization expenses and multi-purpose amortization expenses. Notice of the Ministry of Finance and the State Administration of Taxation on Further Encouraging the Development of Enterprise Income Tax Policies for the Software Industry and the Integrated Circuit Industry (CS [2012] No. 27) clarifies that software purchased by an enterprise as an intangible asset can be appropriately shortened for amortization period.In order to improve the certainty of the policy, No. 40 Announcement clarifies the depreciation and collection method for shortening the amortization period of intangible assets, which is consistent with the collection method of accelerated depreciation of fixed assets, and the additional deduction is calculated for amortization part of pre-tax deduction.
3) Improving the deduction method for expenses across the year: No. 40 Announcement retains the collection requirements in No. 97 Announcement for direct input expense caliber and multi-purpose instrument and equipment rental fees, refines that management fees for the corresponding material costs in research and development expenses shall not be deducted, and further clarifies the treatment of material costs across the year. Item 2 of Article 2 in No. 40 Announcement stipulates that if the enterprise R\&D activities directly form products or the products formed as components are sold externally, the corresponding material costs in the R\&D expenses shall not be deducted. If the product sales and the corresponding material expenses occur in different tax years and the material expenses have been included in the R\&D expenses, the $R \& D$ expenses of the current year can be directly offset by the corresponding material expenses in the year of sales. If the material costs are insufficient, they can be continued to offset after carrying over. This provision solves the problem of needing to revise tax declaration in previous years in actual implementation if the actual occurrence of material costs and the external sales 
of products are not in the same year and it is traced back to the actual occurrence of material expenses. The treatment method has been clarified to facilitate taxpayer operations.

\section{Define Expense Deduction Caliber}

1) Defining the deduction caliber of new product design fees and so forth: CS [2015] No. 119 stipulates the pre-tax additional deduction is allowed for the new product design fee, the new process specification development fee, the clinical trial fee for the development of new drugs, and the on-site test fee for exploration and development technology. No. 40 Announcement further refines the deduction caliber of the fee. Announcement stipulates: New product design fee, new process specification fee, clinical trial fee for new drug development, and field test fee for exploration and development technology refer to the various expenses incurred by the enterprise in the course of new product design, new process specification, clinical trial of new drug development, and on-site test of exploration and development technology.

2) Defining additional deduction caliber for entrusted $R \& D$ : CS [2015] No. 119 stipulates that for the expenses incurred by an enterprise for entrusting external institutions or individuals to carry out research and development activities, $80 \%$ of the actual amount of the expenses is included in the entrusting party's research and development expenses and the additional deduction is calculated, and the trustee may not make additional deductions. No. 97Announcement stipulates that the expenses incurred by an enterprise for entrusting external institutions or individuals to carry out research and development activities may be deducted before tax according to the provision; $80 \%$ of the expenses incurred in research and development activities shall be used as the deduction base in additional deduction. If the individual research and development is entrusted, it shall be deducted before tax by legal and valid vouchers such as invoices issued by individuals. These two documents make provisions that are not consistent with the base of the deductions incurred by external agencies or individuals. CS [2015] No. 119 stipulates $80 \%$ of the actual amount of expenses, and No. 97Announcement stipulates $80 \%$ of the expenses incurred for the research and development activities. Such provision will make it difficult for taxpayers to understand. No. 40Announcement clearly states in Item 3 of Article 7: "The expenses incurred in research and development activities" as stated in Article 3 of the No. 97 in 2015 by the State Administration of Taxation refers to the fees actually paid by the entrusting party to the trustee. This provision clarifies the calculation base for the additional deductions.

\section{SEVERAL ISSUES THAT ENTERPRISES SHOULD PAY ATtENTION TO WHEN ENJOYING THE POLICY OF ENCOURAGING TAX INCENTIVES FOR R\&D}

\section{A. Record Management of $R \& D$ and Non-R\&D Activities}

In the actual R\&D activities of enterprises, the personnel engaged in $R \& D$ are engaged in non- $R \& D$ activities, and the equipment and intangible assets used for $R \& D$ are used for non-R\&D projects. These phenomena are very common. For this, No. 40Announcement has made corresponding provisions. Item 3 of Article 1 in Announcement stipulates that for those who directly engage in the R\&D activities and external $R \& D$ personnel are engaged in non-R\&D activities at the same time, the enterprise shall make necessary records for the activities of its personnel, and the relevant expenses incurred in the actual operation shall be allocated between the $R \& D$ expenses and production and operation expenses according to a reasonable method such as the proportion of actual working hours and the unallocated may not be deducted. At the same time, Item 1 of Article 2 in Announcement stipulates that for the leased instruments and equipments used for the R\&D activities are also used for non-R\&D activities, the enterprise should make the necessary records for the use of its equipments, and the depreciation expenses actually incurred shall be allocated between the R\&D expenses and the production and operation expenses according to a reasonable method such as the actual working hours, and the unallocated may not be deducted. Therefore, when the above-mentioned situations occur, the enterprise must make detailed and comprehensive records of the R\&D activities and non-R\&D activities and allocate expenses reasonably. Otherwise, it will affect the preferential policies for enterprises to enjoy pre-tax additional deduction.

\section{B. Equity Incentives for the R\&D Personnel Included in the Scope of Additional Deductions Must Comply with Regulations}

The new policy clarifies that labor costs for pre-tax additional deductions, wages and salaries include expenditures on $R \& D$ personnel equity incentives that can be deducted before tax. This provision is in line with the actual situation of social and economic development. At the same time, we must pay attention to the fact that the shareholding incentives expenditures that enjoy additional deductions need to comply with the relevant provisions of "Notice of the State Administration of Taxation on the Issues Concerning the Treatment of Enterprise Income Taxes in the Implementation of Equity Incentive Plans by Chinese Resident Enterprises" (No. 18Announcement by State Administration of Taxation in 2012).

\section{Joint Management of New and Old Policies}

In recent years, China has introduced a number of pre-tax additional deductible tax policies for R\&D expenses that encourage enterprise innovation and increase R\&D investment. When enterprises enjoy these preferential policies, they must pay attention to the effectiveness of these policies and pay attention to the joint of new and old policies. No. 40Announcement is applicable to the final settlement in 2017 and subsequent years. The tax treatment has not been adjusted 
in previous years. Articles 1, Item 1 of Article 2, Item 2 of Article 2, and Item4of Article 2in No. 97 Announcement shall be repealed at the same time.

\section{CONCLUSION}

Enterprises make full use of tax policies and enjoy tax reductions after increasing the research and development investment, which is conducive to promoting technological upgrading and rebuilding of enterprises. It not only helps to improve the core competitiveness of enterprises, but also helps to establish a technological innovation system with enterprises as the mainstay, market-oriented, and deep integration of production, education and research, promote the transformation of scientific and technological achievements, and drive the upgrading of the entire social economy.

\section{REFERENCES}

[1] Guo Yingjie. R\&D Expenses Additional Deductions for New Regulations. [J] Chinese CPA, 2018, (2). (in Chinese)

[2] Chen Yuzhuo, Ye Meiping, Gu Jun. Interpretation and Case Analysis of Pre-tax Additional Deduction Preferential Policy for the R\&D Expenses (I). [J] China Tax, 2017, (7). (in Chinese)

[3] Chen Yuzhuo, Ye Meiping, Gu Jun. Interpretation and Case Analysis of Pre-tax Additional Deduction Preferential Policy for the R\&D Expenses (II). [J] China Tax, 2017, (8). (in Chinese) 